
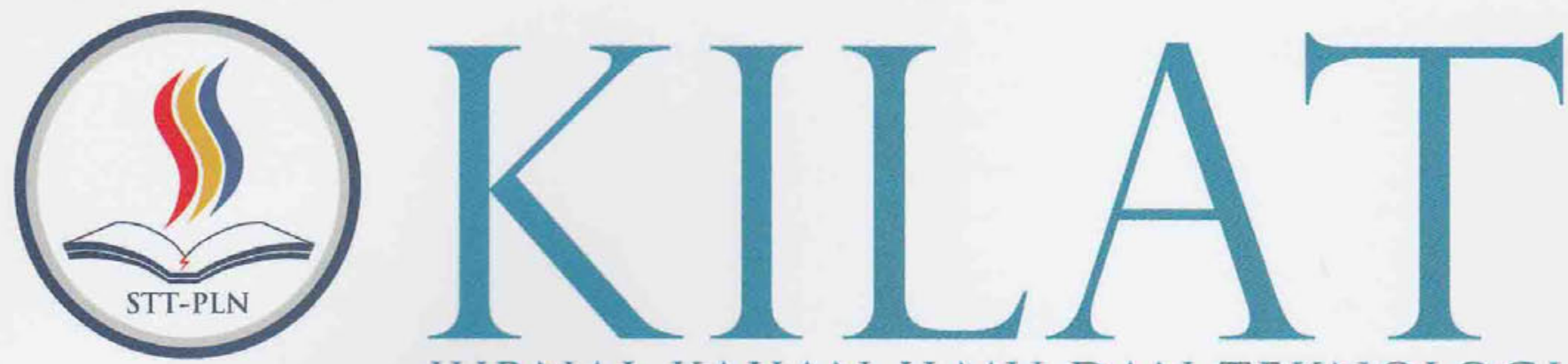

JURNAL KAJIAN ILMU DAN TEKNOLOGI

Endah Lestari: Irma Wirantina K: Ranti Hidayawanti

Faisal:

Muhammad Ridwan: Mardawati

Gita Puspa Artiani; Indah Handayasari

Kresna Ramanda; Irmawati Carolina

Ratna Mutu Manikam;

Farid Setiawan

Rayung Wulan

Roni Kartika Pramuyanti

Rr. Mekar Ageng Kinasti; Djoko Nugroho Notodisuryo

Satria; Ayu Setiawati Agustini

Syam Gunawan: Pritasari Palupiningsih

Ali Ridho Gumelar: Anton: Ummu Radiyah

M. Yoga Distra Sudirman: Yessy Fitriani
ANALISA TAMAN ATAP DALAM UPAYA MENGURANGI LIMPASAN AIR HUJAN PADA BANGUNAN PERKOTAAN

OPTIMASI DIAGRAM LAYANAN PEMBELIAN DALAM MENDUKUNG MANAJEMEN HUBUNGAN PELANGGAN

OPTIMALISASI PENGOLAHAN SAMPAH ORGANIK DENGAN TEKNOLOGI BIODIGESTER SEBAGAI UPAYA KONSERVASI LINGKUNGAN

SELEKSI FITUR ALGORITMA NEURAL NETWORK MENGGUNAKAN PARTICLE SWARM OPTIMIZATION UNTUK MEMPREDIKSI KELAHIRAN PREMATUR

RANCANG BANGUN MEDIA BELAJAR FISIKA DASAR UNTUK MAHASISWA BERBASIS ANDROID

ANALISIS GLOBAL POSITIONING INFRASTRUKTUR DAN JARINGAN SOSIAL MEDIA DALAM BISNIS APLIKASI TRANSPORTASI DARAT ONLINE DI JAKARTA

PENGARUH INOVASI ANTENA PADA SIARAN TELEVISI MOBIL

PEMANFAATAN LIMBAH PEMBAKARAN BATUBARA (BOTTOM ASH) PADA PLTU SURALAYA SEBAGAI MEDIA TANAM DALAM UPAYA MENGURANGI

PENCEMARAN LINGKUNGAN

PENERAPAN METODE GRAPHIC RATING SCALE (GRS) DALAM PENILAIAN KINERJA KARYAWAN

PEMBENTUKAN MODEL KLASIFIKASI DATA LAMA STUDI MAHASISWA STMIK INDONESIA MENGGUNAKAN DECISION TREE DENGAN ALGORITMA NBTREE

IMPLEMENTASI LOAD BALANCING DENGAN ALGORITMA EQUAL COST MULTI PATH (ECMP)

RANCANGAN SISTEM PENILAIAN HASIL KINERJA MULTI COMPANY DAN CROSS BUSINESS SECTOR 


\title{
RANCANGAN SISTEM PENILAIAN HASIL KINERJA MULTI COMPANY DAN CROSS BUSINESS SECTOR
}

\author{
M. Yoga Distra Sudirman ${ }^{1)}$; Yessy Fitriani' ${ }^{2)}$ \\ Jurusan Teknik Informatika, Sekolah Tinggi Teknik PLN \\ ${ }^{1}$ Email : yogadistra@sttpln.ac.id \\ Jurusan Teknik Informatika, Sekolah Tinggi Teknik PLN \\ ${ }^{2}$ Email : yessy.fitriani@sttpln.ac.id
}

\begin{abstract}
ABSTRAK
Setiap instansi memiliki ciri khas tersendiri dan diberikan otoritas dalam memanajemen keuangannya. Yayasan pendidikan dan kesejahteraan PT.PLN (persero) (YPK-PLN) memliki 14 afiliasi perusahaan. Setiap afiliasi diwajibkan melaporkan keuangan mereka secara berkala kepada YPK-PLN. Beragamnya bidang usaha dan lokasi yang berbeda-beda membuat YPK-PLN mengalami kesulitan dalam mendapatkan data posisi keuangan pada setiap afiliasi. Laporan keuangan ini menjadi salah satu acuan YPK-PLN untuk melihat keadaan anak perusahaannya tersebut. Laporan keuangan tersebut harus dilaporkan setiap triwulan dalam satu tahun. Laporan keuangan tersebut meliputi laporan keuangan neraca, labarugi dan aruskas. Tujuan penelitian ini adalah merancang dan membangun sistem yang dapat menyatukan semua laporan keuangan masing-masing afiliasi dan kemudian dihitung hasil kinerjanya. Hasil kinerjanya yang dimasksud adalah menghitung Operating Ratio, Average Collection Period, Return on Equity, Net Profit Margin, Current Ratio dan Debt to Equity Ratio. Penelitian ini dilakukan dengan metodologi waterfall untuk mengembangkan perangkat lunaknya. Untuk merancang sistem yang akan dibangun akan menggunakan UML 2.0. Dalam pengembangan perangkat lunaknya akan digunakan bahasa php dengan framework codeigniter. Basis data yang digunakan adalah SQL DBMS MariaDB dengan Apache 2 sebagai web servernya. Hasil penelitian juga membuktikan bahwa Hasil Kinerja dari rasio keuangan afiliasi memiliki peranan yang penting untuk YPK-PLN dalam menentukan apakah menanamkan saham pada perusahaan yang bersangkutan adalah keputusan yang tepat.
\end{abstract}

Kata Kunci : Sistem Informasi, SDLC, waterfall, UML 2.0, MariaDB, Apache2

\begin{abstract}
Each agency has its own characteristics and given authority in managing its finances. Foundation education and welfare PT.PLN (Persero) (YPK-PLN) has 14 affiliated companies. Each affiliate is required to report their financial periodically to YPK-PLN. The diversity of business fields and different locations makes YPK-PLN difficult to obtain financial position data on each affiliate. This financial report becomes one of the YPK-PLN reference to see the state of its subsidiary. The financial statements should be reported quarterly in a year. These financial statements include the balance sheet financial statements, labels and flows. The purpose of this study is to design and build a system that can unify all the financial statements of each affiliate and then calculated the results of its performance. The result of its performance is calculated dimasksud Operating Ratio, Average Collection Period, Return on Equity, Net Profit Margin, Current Ratio and Debt to Equity Ratio. This research was conducted with waterfall methodology to develop the software. To design the system to be built will use UML 2.0. In the development of the software will be used php language with codeigniter framework. The database used is SQL DBMS MariaDB with Apache 2 as its web server. The results also proved that the Performance Results of the affiliate financial ratios have an important role for YPK-PLN in determining whether to invest shares in the company concerned is the right decision.
\end{abstract}

Keywords: Information System, SDLC, waterfall, UML 2.0, MariaDB, Apache2

\section{PENDAHULUAN}

\subsection{Latar Belakang}

YPK-PLN memiliki 14 afiliasi yang berbentuk anak perusahaan yang berbeda jenis bidang usahanya. Adapun ke -14 anak perusahaan tersebut antara lain PT. Andika Energindo, PT. Bajragraha Entranusa, PT. Citacontract, PT. Masaji Prayasa Cargo, PT. Data Energi Infomedia, PT. Usaha Jasa Prima Karya, PT. Lisna Syifa Prima, PT. Asuransi Tugu Kresna, PT. Wismatata Eltra Jaya, PT. Wismatata Eltra Perkasa, PT. Bakti Energi Sejahtera, PT. Matlamat Cakra Canggih, PT.
Sumbetri Megah, PT. Kepurun Pawana Indonesia. Seluruh anak perusahaan wajib melaporkan keuangannya setiap triwulan sesuai dengan permintaan YPK-PLN.

Laporan keuangan ini dinilai oleh pihak YPKPLN sebagai kinerja masing-masing anak perusahaan. Berbagai jenis bidang usaha tentu membuat beragam macam bentuk laporan keuangannya, dan lokasi tiap anak perusahaan juga berbeda-beda bahkan hingga ke Sumatera Utara. Untuk kemudahan komunikasi dan penampuangan data lebih terdigitalisasi sistem ini dibuat dengan segala kemampuan yang diinginkan oleh YPK-PLN. 
Sistem Informasi Laporan Manajemen Keuangan dan Hasil Kinerja ini memberikan informasi mengenai keadaan keuangan per triwulan setiap anak perusahaan YPK-PLN. Hasil laporan keuangan tersebut yakni neraca keuangan, Laba Rugi dan Arus Kas. Laporan keuangan tersebut wajib di isi oleh seluruh anak perusahaan YPK-PLN. Dengan bidang usaha yang berbeda-beda, maka laporan keuangan pun akan berbeda disetiap bidang usaha yang dijalani oleh anak perusahaan YPK-PLN. Dari hasil inputan keuangan dari anak perusahaan, pada dashboard utama pihak yayasan akan diberikan fitur monitoring pengisian laporan keuangan dan laporan hasil kinerja dengan berbagai jenis bidan usaha. Laporan hasil kenerja yang akan diberikan pada dashboard antara lain Operating Ratio, Average Collection Period, Return on Equity, Net Profit Margin, Current Ratio dan Debt to Equity Ratio.

Solusi yang ditawarkan adalah membuat sistem informasi berbasis web yang dapat di akses dimana saja dan selalu mendapatkan data yang teraktual. Sistem ini akan dibekali dashboard untuk eksekutif dan administrator untuk setiap pengguna atau anak perusahaan. Dalam merancang sistem ini akan mengikuti kaidah SDLC waterfall dan menggunakan beberapa diagram UML 2.0 dalam merancang sistem informasinya. Sistem ini akan diberikan nama Salaman (Sistem Informasi Laporan Manajemen Keuangan dan Hasil Kinerja).

Berdasarkan latar belakang di atas, penulis menganggap web aplikasi ini sangat bermanfaat dan lebih praktis untuk mempermudah dan menjembatani pihak yayasan dan afiliasi perusahaan dalam mengakses informasi tentang laporan keuangan di Yayasan Pendidikan dan Kesejahteraan PT.PLN. Oleh karena itu penulis mengambil judul "Sistem Penilaian Hasil Kinerja Multi Company dan Cross Business Sector".

\subsection{Tujuan Penelitian}

Dari latar belakang diatas, pada jurnal ini akan di paparkan mengenai:

Bagaimana merancang sistem penilaian hasil kinerja multi compay dan cross business sector menggunakan tahapan SDLC dan UML 2.0?

\section{METODOLOGI PENELITIAN}

Dalam pengembangan sistem informasi ini, akan mengikuti salah satu metode SDLC dalam pengembangannya yakni waterfall. Adapun metodologi penelitian sistem informasi ini adalah sebagai berikut :

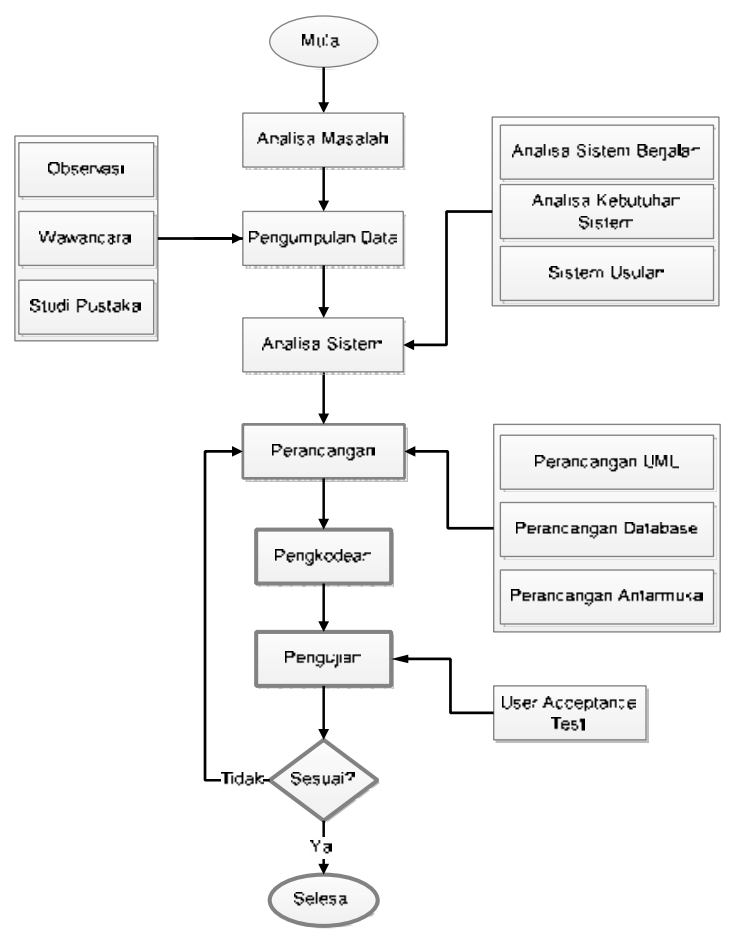

Gambar 1 Metode Penelitian Sistem Penilaian Hasil Kineja

Keseluruhan tahapan penelitian diatas akan dijelaskan tahap demi tahap sebagai berikut :

\section{Analisa Masalah}

Merupakan tahap awal riset yang dilakukan untuk melihat dan memahami masalah yang terdapat di YPK-PLN. Hasil kajian ini akan menjadi dasar acuan untuk melakukan perancangan suatu aplikasi yang memudahkan komunikasi pihak yayasan dan afiliasi dalam hal laporan keuangan.

\section{Pengumpulan Data}

Pengumpulan data adalah mengumpulkan bahan-bahan yang diperlukan dalam penyusunan tugas akhir ini, penulis menggunakan metode observasi, wawancara dan studi pustaka.

\section{Observasi}

Observasi dilakukan dengan cara mengamati langsung proses pengoperasian setiap fungsi pada aplikasi salaman.

\section{Wawancara}

Pada pembuatan aplikasi ini, pengumpulan data dilakukan melalui wawancara secara mendalam dengan responden yang diperlukan. Penulis mengumpulkan teori dan pustaka yang berkaitan dengan rasio keuangan dan hasil kinerja keuangan sebagai referensi untuk menyelesaikan masalah tersebut.

\section{HASIL DAN ANALISA}

\subsection{Analisa Sistem}

Penulis melakukan identifikasi proses sistem berjalan dan sistem kebutuhan, dimana hasil dari analisa digunakan untuk membuat skema alur 
proses pengembangan sistem usulan aplikasi. Penulis juga melakukan identifikasi informasi yang dibutuhkan untuk membangun sistem yang diusulkan. Informasi yang didapat akan digunakan untuk membangun sistem yang akan diusulkan dengan mengikuti skema alur proses sistem yang telah dianalisa.

\subsection{Perancangan Sistem}

- Perancangan Sistem (UML)

Merepresentasikan gambaran dari sistem yang dibuat dengan menggunakan notasi UML.

- $\quad$ Perancangan Basis Data

Proses perancangan basis data ini adalah merancang kebutuhan tabel yang akan digunakan untuk penyimpanan data.

- Perancangan Antar Muka

Merancang antar muka yang merupakan antar muka interaktif antara user dengan sistem.

\subsection{Pengkodean}

Perancangan diimplementasikan dengan menggunakan bahasa pemograman Perl Hypertext Processor (PHP) dan Hypertext Markup Language (HTML) sebagai aplikasi berbasis web.

\subsection{Pengujian}

Tahap selanjutnya adalah melakukan pengujian terhadap program yang telah dibuat. Apabila pengujian gagal maka diperlukan adanya penelusuran kembali setiap perancangan yang telah dilakukan untuk menemukan penyebab kegagalan sampai tidak ada lagi eror dalam aplikasi ini.

Pengujian dilakukan dengan metode UAT (User Acceptance Test), yaitu test yang dilakukan oleh user-user / pengguna terhadap sistem yang baru atau sistem yang telah diubah dengan tujuan memperoleh persetujuan terhadap sistem yang sedang di testing dan go live (siap dipakai).

\subsection{Kebutuhan sistem}

Setelah melakukan wawancara dengan admin dan operator Aplikasi Salaman disimpulkan bahwa kebutuhan untuk pengembangan sistem Salaman maka didapatkanlah poin poin sebagai berikut :

1. Format keuangan setiap afiliasi dapat berubah secara dinamis sesuai dengan kebutuhan afiliasi dengan persetujuan YPK-PLN

2. Kemudahan dalam menginput laporan masih kurang seperti : saat memasukkan nilai uang kedalam form belum ada separator koma untuk memudahkan user afiliasi dalam mengkoreksi nilai yang dimasukkan

3. Sistem monitoring deviasi labarugi oleh YPK PLN kepada afiliasi belum berjalan dengan baik.

4. Belum ada hasil kinerja sebagai tolak ukur YPK dalam memonitoring afiliasi.

Dalam proses pembuatan aplikasi ini, Penulis menggunakan spesifikasi perangkat sebagai berikut.

1. Perangkat Keras

a. Laptop intel core i5 / AMD 10

b. L3 Cache $2 \mathrm{MB}$

c. DDR3 8GB

d. $500 \mathrm{~GB}$

e. LCD 18.5" f. HP Proliant DL380 G7

g. HDD SATA 3G MDL 500GB $72 \mathrm{~K} \mathrm{rpm}$

h. RDIMM $8 G B$

2. Perangkat Lunak
a. Windows 1064 bit
b. Ubuntu server $14.0464 \mathrm{bit}$
c. Apache Server
d. Database MariaDB
e. PHP 5.04
f. NetBeans 7.4
g. Notepad ++
h. Codeigniter
i. Ms. Office 2016
j. Mozilla Firefox
k. Safari
I. Ms. Visio 2015

\subsection{Sistem Usulan}

Untuk menjelaskan secara singkat sistem Penilaian Hasil Kinerja Multi Company dan Cross Business Sector adalah sebagai berikut:

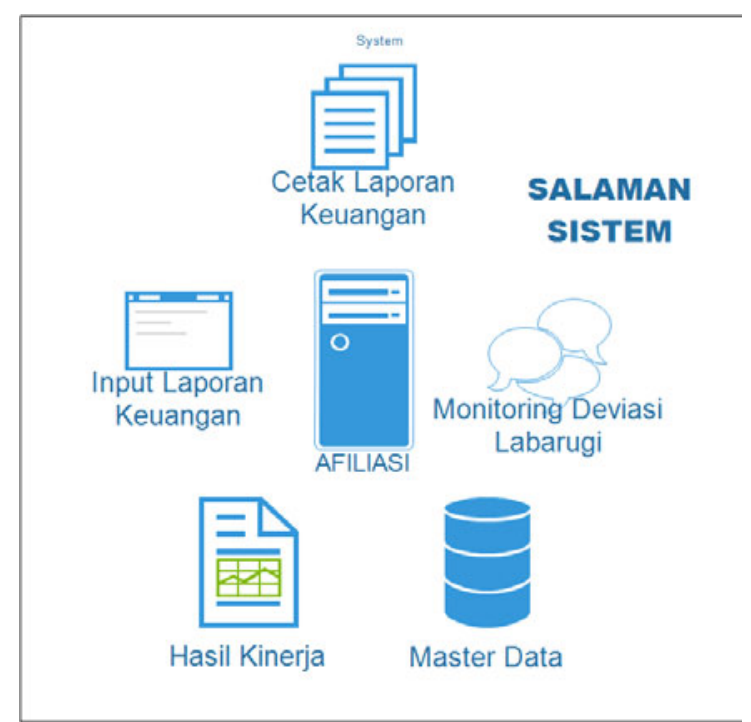

Gambar 2 Usulan Sistem Penilaian Hasil Kinerja

Gambar diatas menjelaskan gambaran sistem salaman yang diusulkan dimana dalam satu boundary hanya terdapat satu sistem yang mampu menangani seluruh kebutuhan afiliasi dan YPK. Dalam sistem aplikasi Salaman yang baru ini terdapat tiga fungsi tambahan selain input laporan keuangan dan cetak laporan keuangan yaitu monitoring deviasi pada laporan labarugi, hasil kinerja dan master data.

\subsection{Rancangan Sistem}

Untuk menggambarkan seluruh fitur yang ada didalam sistem penilaian hasil kinerja digambarkan pada diagram use case. Adapun diagram use case fitur sistem sebagai berikut: 


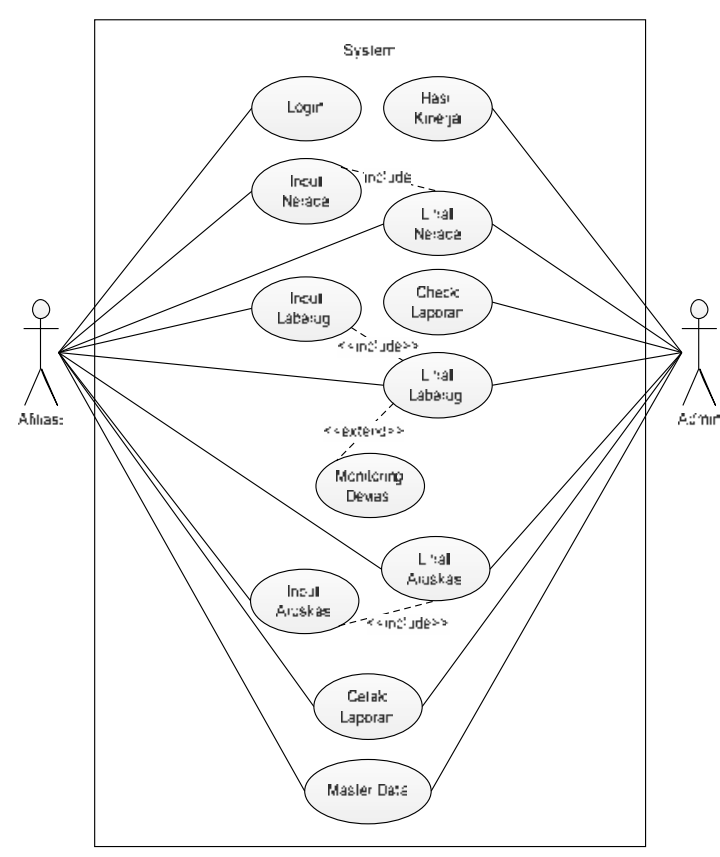

Gambar 3 Diagram Usecase Sistem

Dengan struktur sistem dengan digambarkan dalam class diagram berikut ini :

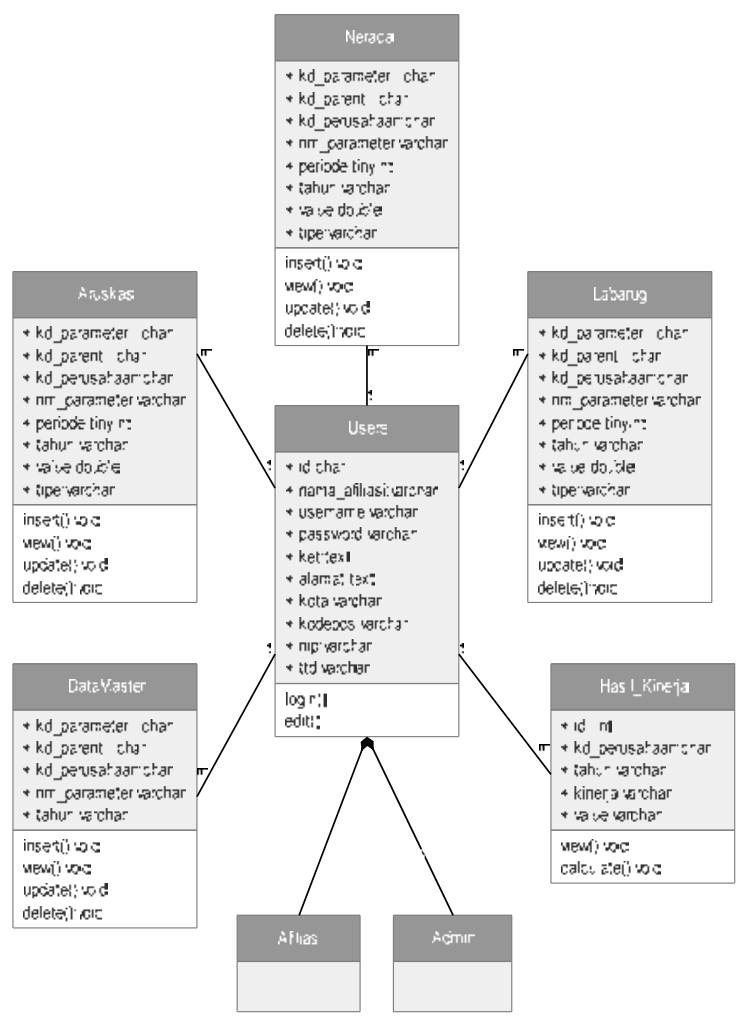

Gambar 4 Diagram Class Sistem

Untuk menjabarkan behavioural dari fitur yang telah disampaikan dalam usecase diagram tersebut dapat dilihat dalam beberapa diagram activity berikut ini:

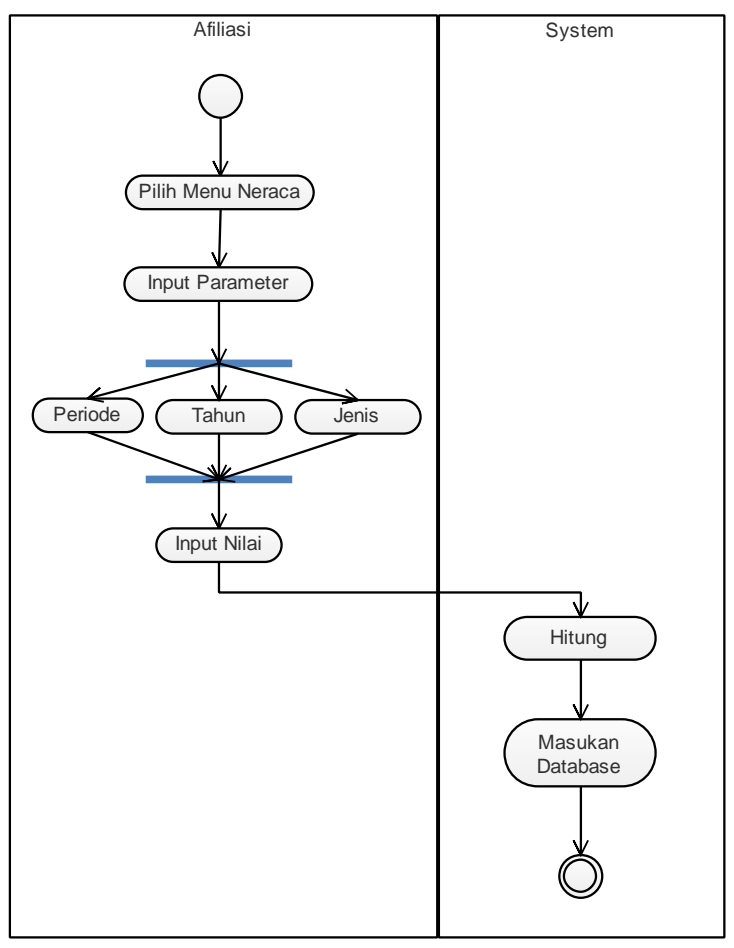

Gambar 5 Aktivitas fitur input neraca

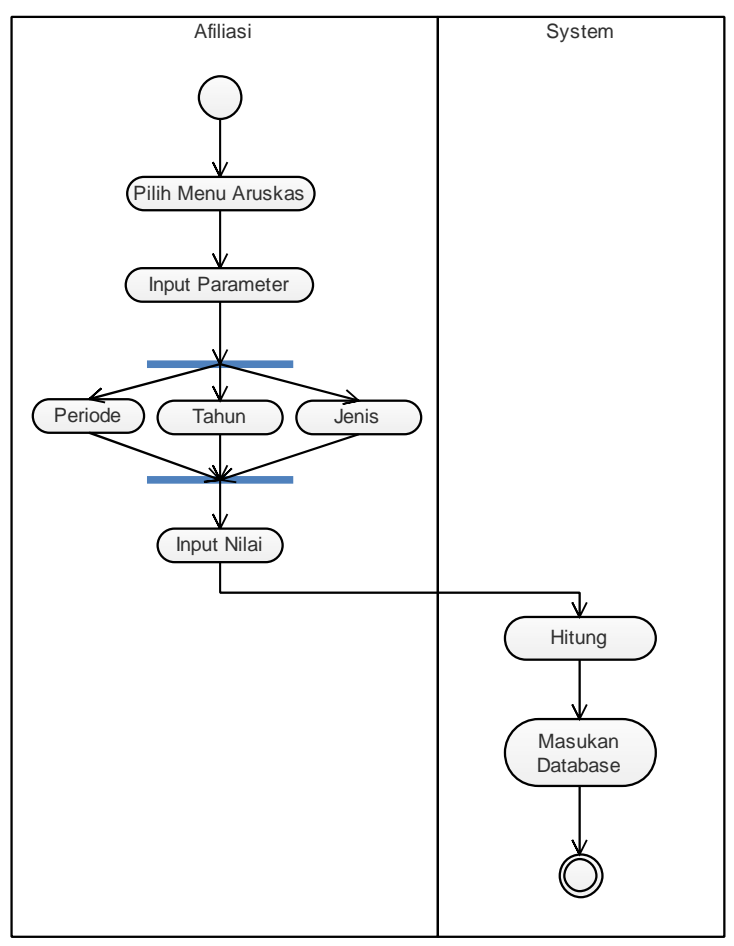

Gambar 6 Aktivitas input arus kas 


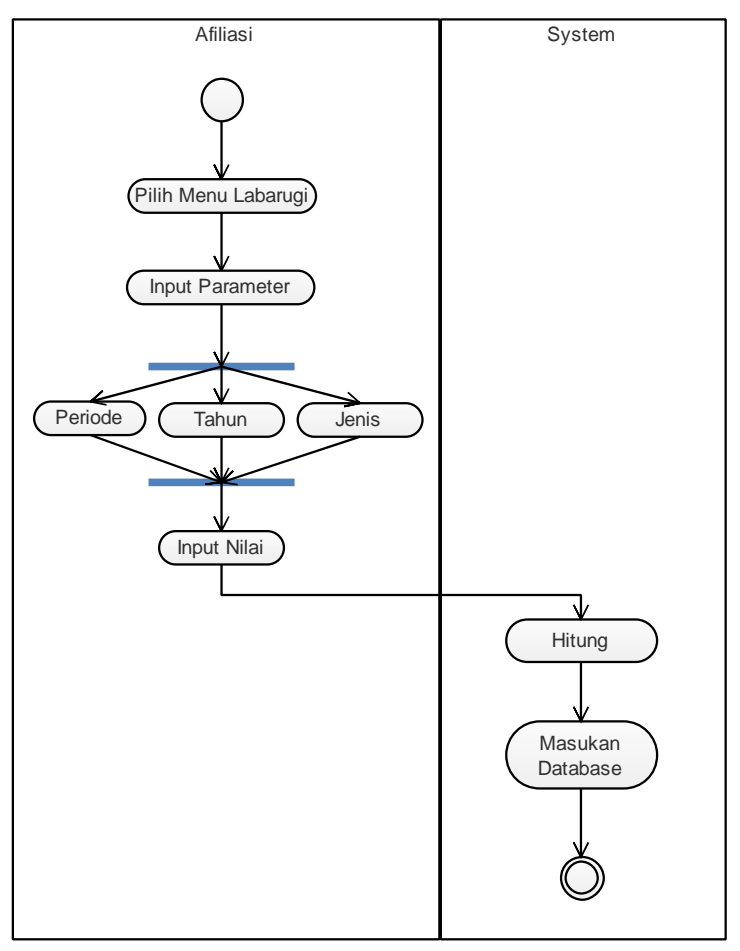

Gambar 7 Aktivitas Input Labarugi

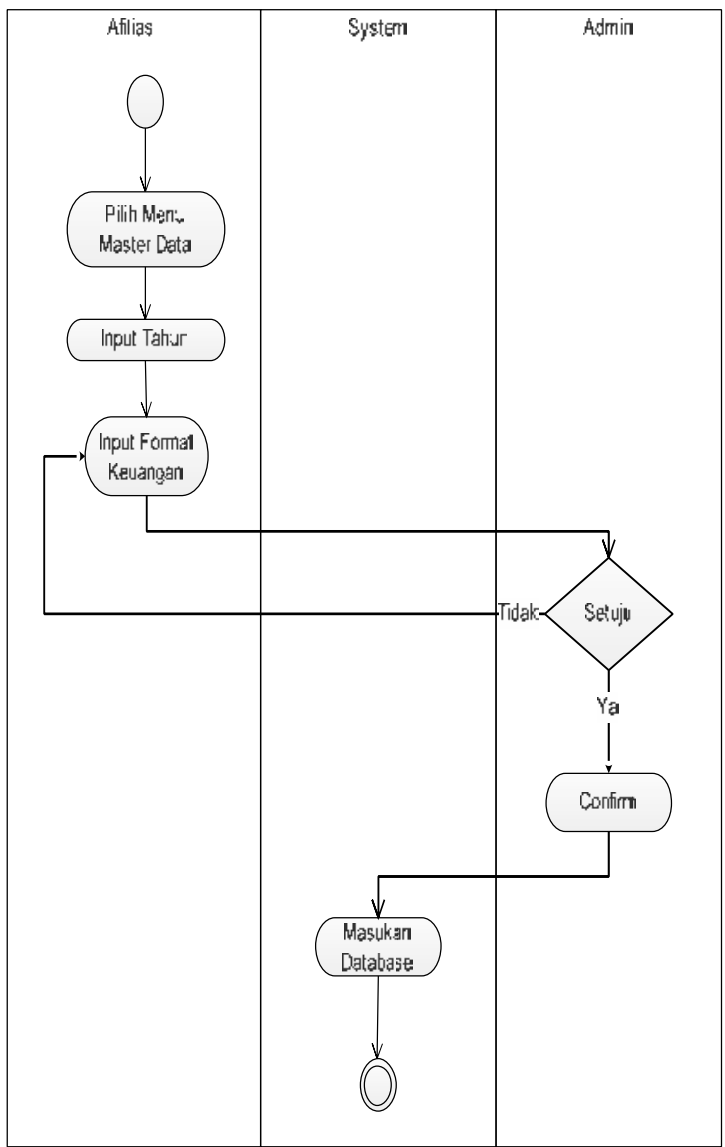

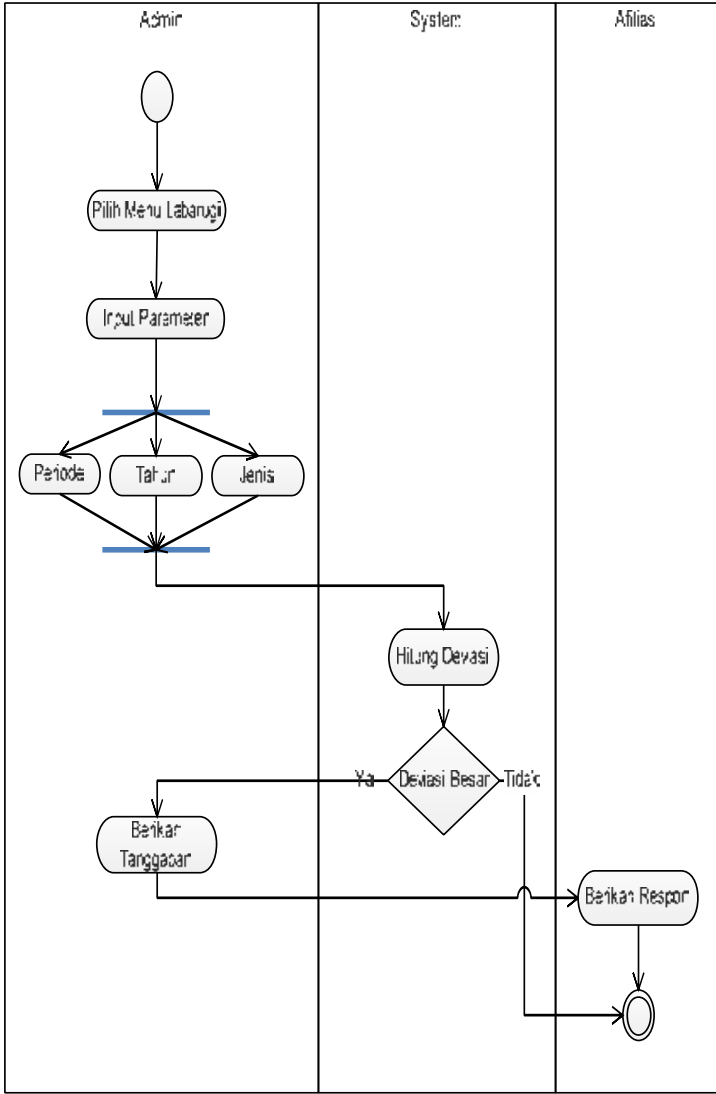

Gambar 9 Aktivitas Monitoring Deviasi

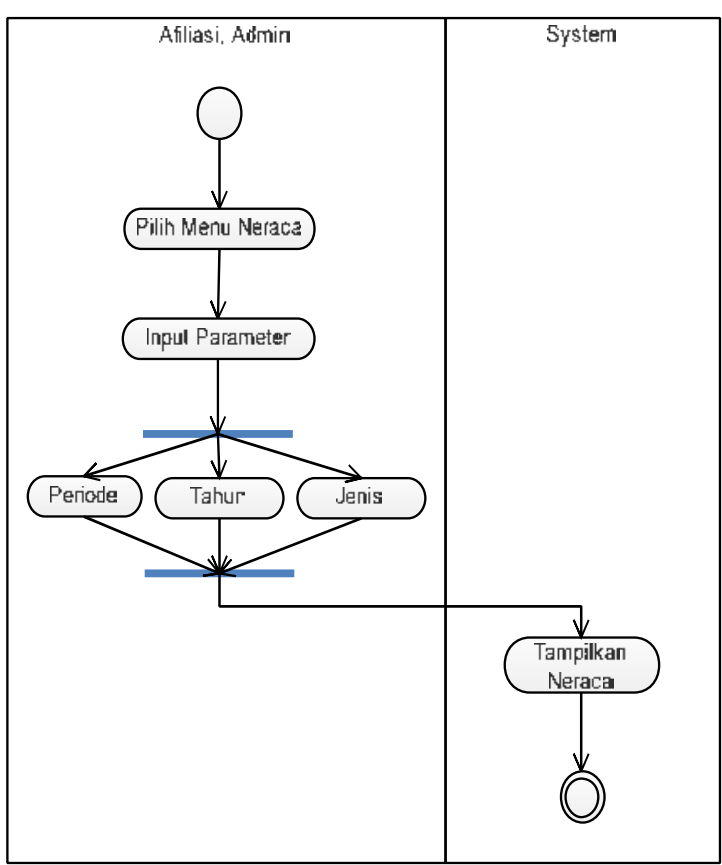

Gambar 10 Aktivitas Melihat Neraca

Gambar 8 Aktivitas Master Data 


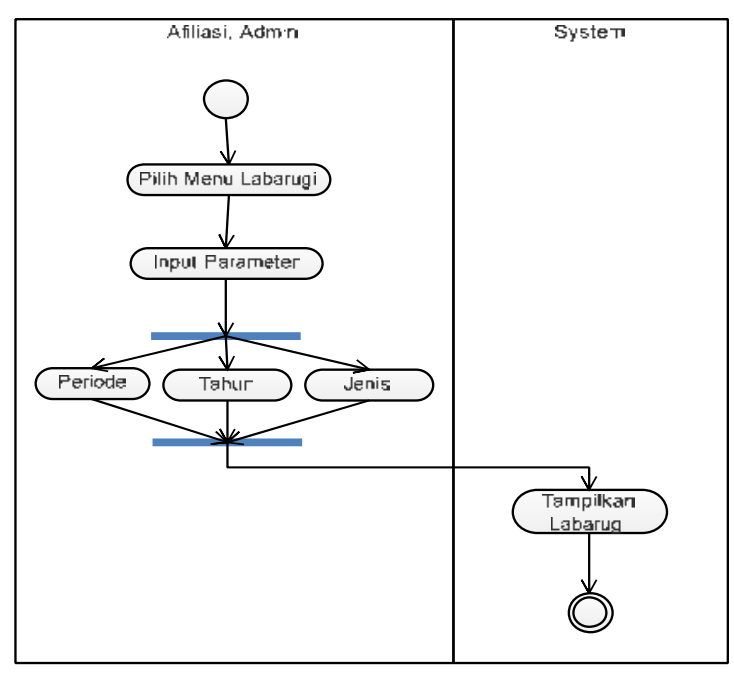

Gambar 11 Aktivitas Melihat Labarugi

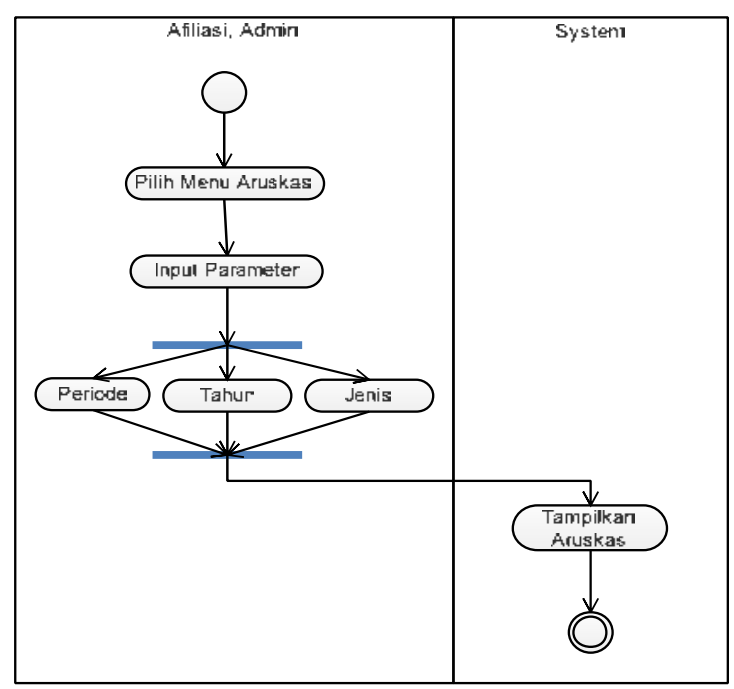

Gambar 12 Aktivitas melihat aruskas

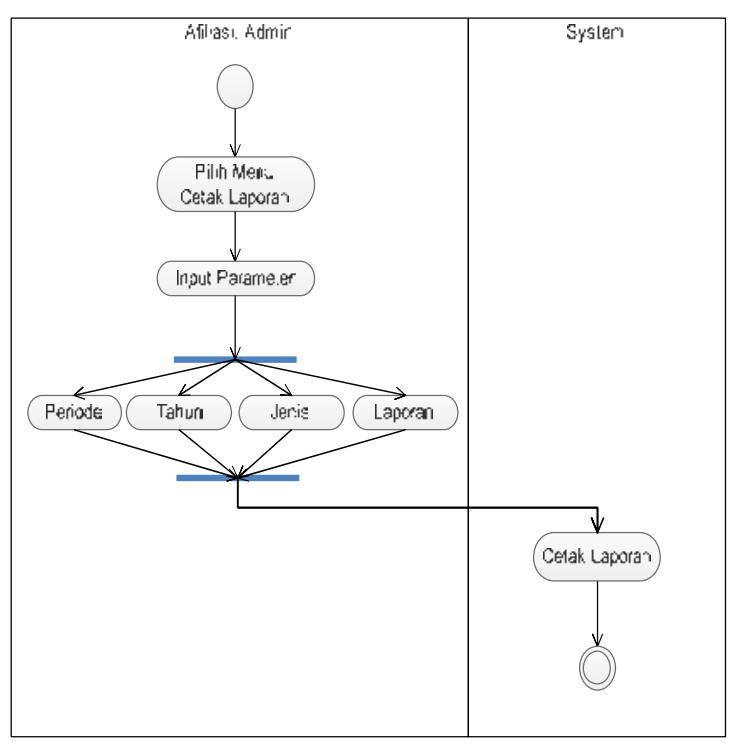

Gambar 13 Aktivitas cetak laporan

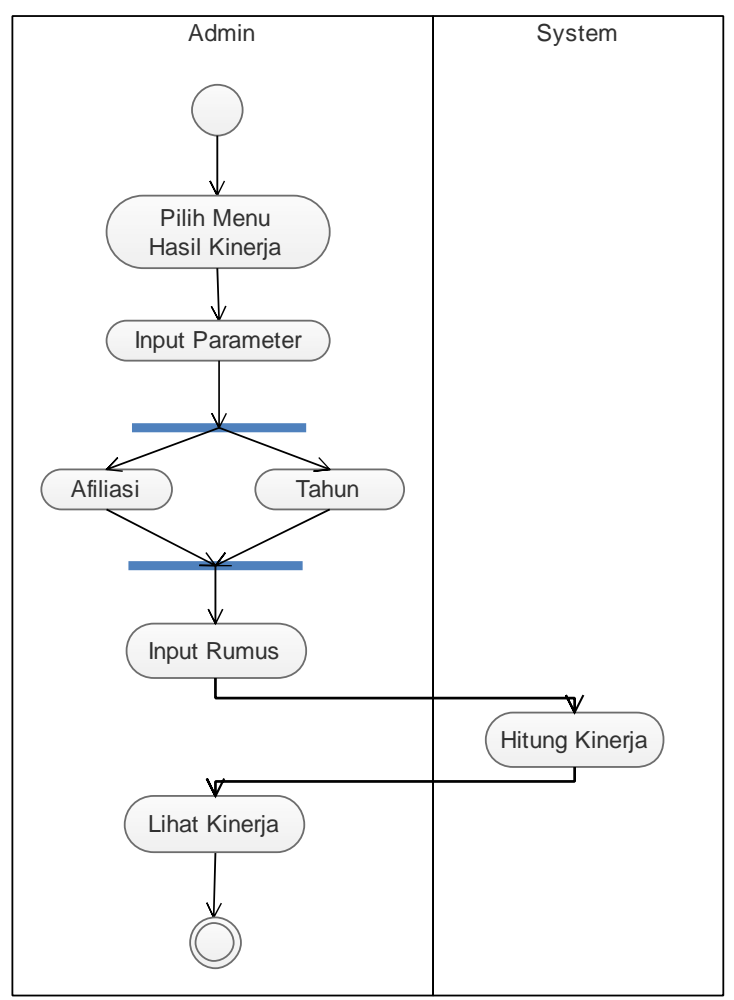

Gambar 14 Aktivitas hasil kinerja

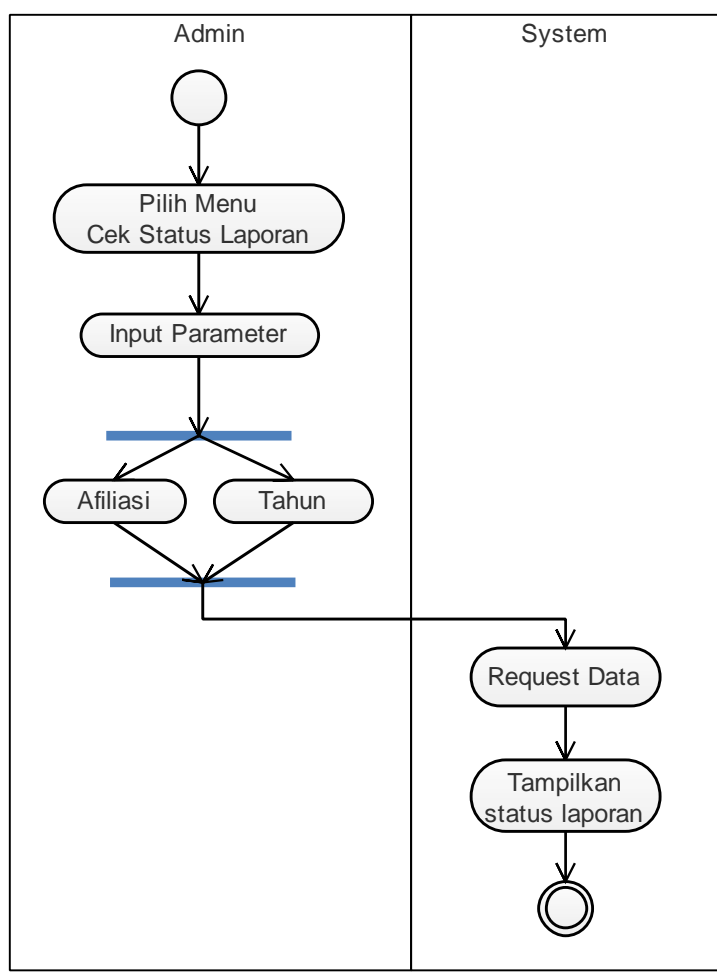

Gambar 15 Aktivitas lihat status laporan

\subsection{Rancangan Basis Data}

Basis data dibuat berdasarkan dari diagram kelas yang telah dibuat sesuai dengan gambar 4 . Adapun tabel yang terbentuk melalui proses normalisasi dari level 0 yang didapat dari atribut 
setiap kelas. Adapun tabel yang dibentuk setelah bentuk normal 3 adalah sebagai berikut:

1. Tabel afiliasi
a. Id_afiliasi char(3)
b. Nāma_afiliasi varchar(40)
c. Username varchar(20)
d. password char(32) MD5
e. keterangan text
f. alamat text
g. kota varchar(20)
h. kodepos int(6)
i. nip varchar(15)
j. ttd varchar(20)

2. aruskas_id / labarudi_id / neraca_id
a. kd_param char(3)
b. kd parent char(3)
c. kd_perusahaan(3)
d. nm_param varchar(90)
e. tahun int(4)

3. aruskas_parent_id / labarugi_parent_id / neraca_parent_id
a. kd_parent char(3)
b. kd_perusahaan(3)
c. nm_param varchar(90)
d. tahun int(4)

4. aruskas_parent_value / labarugi_parent_value / neraca_parent_value
a. kd_parent char(3)
b. kd_perusahaan char(3)
c. periode int(11)
d. tahun int(11)
e. value double
f. createdby varchar(15)
g. createdate date
h. updatedby varchar(15)
i. updateddate date
j. tipe tinyint(4)

5. aruskas_value / labarugi_value / neraca_value
a. kd_param char(3)
b. Kd_parent char(3)
c. Kd_perusahaan char(3)
d. periode int(11)
e. tahun int(11)
f. value double
g. createdby varchar(15)
h. createdate date
i. updatedby varchar(15)
j. updateddate date
k. tipe tinyint(4)

6. kinerja_rumus
a. kd_perusahaan char(3)
b. tahun int(4)
c. pendapatan varchar(3)
d. labakotor varchar(3)
e. piutang varchar(3)
f. piutanglain varchar(3)
g. lababersih varchar(3)
h. ekuitas varchar(3)
i. aset var char(3)
j. liabilitaslancar varchar(3)
k. liabilitasjp varchar(3)
I. ekulia varchar(3)

\subsection{Teknik Analisis}

Analisis data dilakukan oleh peneliti untuk menjawab pokok permasalahan yang ada melalui data dan informasi yang diperoleh dalam penelitian.
Analisis data diperlukan untuk mendapatkan gambaran tentang perhitungan Operating Ratio, Average Collection Period, Return on Equity, Net Profit Margin, Current Ratio, Debt to Equity Ratio pada kinerja afiliasi YPK-PLN.

Peneliti melakukan observasi dan wawancara kepada admin dan operator aplikasi "salaman". Observasi dilakukan dengan cara mengamati secara langsung cara kerja input laporan neraca, labarugi dan neraca oleh beberapa afiliasi dan proses operator dan admin dalam menggunakan fungsi-fungsi didalamnya. Wawancara dilakukan secara mendalam, sehingga responden dapat memberikan informasi yang tidak terbatas dari berbagai perspektif. Semua wawancara yang peneliti dapatkan dibuatkan transkrip dan disimpan dalam file teks.

Kinerja rasio keuangan yang dipilih untuk diterapkan pada aplikasi diantaranya adalah :

1. Operating Ratio

Operating Ratio digunakan untuk mengukur biaya operasi per rupiah penjualan, semakin kecil angka rasio menunjukan kinerja yang semakin baik. Rumusnya sebagai berikut :

Operating Ratio $=\frac{\text { Pendapatan Operasi-Laba Kotor }}{\text { Pendapatan Operasi }} \times 100 \%$

\section{Average Collection Period}

Average Collection Period digunakan untuk mengukur periode rata-rata yang diperlukan untuk mengumpulkan piutang (dalam satuan hari). Jika menghasilkan angka yang semakin kecil menunjukan hasil yang semakin baik. Rumusnya adalah sebagai berikut :

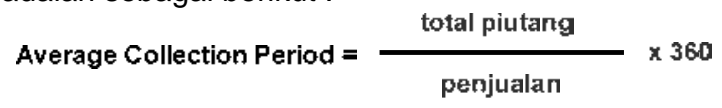

\section{Return on Equity}

Return on Equity (ROE) adalah rasio profitabilitas yang membandingkan antar laba bersih (net profit) perusahaan dengan aset bersihnya (ekuitas atau modal). Rasio ini mengukur berapa banyak keuntungan yang dihasilkan oleh Perusahaan dibandingkan dengan modal yang disetor oleh Pemegang Saham. Rumusnya adalah sebagai berikut :

$$
\operatorname{ROE}=\frac{\text { Laba bersih (net profit) }}{\text { ekuitas (equity) }}
$$

\section{Net Profit Margin}

Net Profit Margin (NPM) adalah rasio yang digunakan untuk menunjukkan kemampuan perusahaan dalam menghasilkan keuntungan bersih. Menurut Bastian dan Suhardjono (2006), Net Profit Margin adalah perbandingan antara laba bersih dengan penjualan. Rumusnya adalah sebagai berikut :

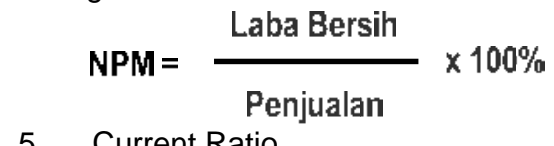

5. Current Ratio

Current ratio (rasio lancar) adalah rasio yang sangat berguna untuk mengukur kemampuan perusahaan dalam melunasi kewajiban-kewajiban 
jangka pendeknya, dimana dapat diketahui sampai seberapa jauh sebenarnya jumlah aktiva lancar perusahaan dapat menjamin utang lancarnya. Rumusnya adalah sebagai berikut :

\section{Current ratio $=\frac{\text { Aktiva Lancar }}{\text { Utang Lancar }} \times 100 \%$}

6. Debt to Equity Ratio

Ratio ini digunakan untuk mengukur bagian modal sendiri yang dijadikan jaminan untuk keseluruhan kewajiban atau hutang. Rumus untuk menghitungnya adalah sebagai berikut :

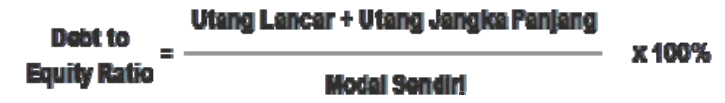

3.10 Rancangan Tampilan

Berikut acuan rancangan untuk tampilan sistem yang akan dibangun.

\begin{tabular}{|l|l|}
\hline Salaman Apps' & $\square$ [Nama afliasi: \\
\cline { 2 - 2 } Home & \\
Form InpLt & \\
Data Table & \\
Print PDF & \\
Master Data & \\
Logout & \\
& \\
& \\
\hline
\end{tabular}

Gambar 16 Rancangan Tampilan Home

\begin{tabular}{|c|c|c|}
\hline Salaman Apps! & & $M$ [Nama Afliasi \\
\hline Home & Perioce & \\
\hline Form InpLt & Tahur & \\
\hline Data Table & Data & \\
\hline Print PDF & Subern I & \\
\hline Master Data & & \\
\hline Logout & & \\
\hline
\end{tabular}

Gambar 17 Form input periode

\begin{tabular}{|c|c|}
\hline Salaman Apps! & $\mathcal{D}_{\text {[Nama Afliasa }]}$ \\
\hline Home & Anus kas dari akliftas pperasi \\
\hline Form Input & \\
\hline Data Table & Item \\
\hline Print FDF & \\
\hline Master Data & \\
\hline Logcut & Iten \\
\hline & Subrit \\
\hline
\end{tabular}

Gambar 18 tampilan form inputan

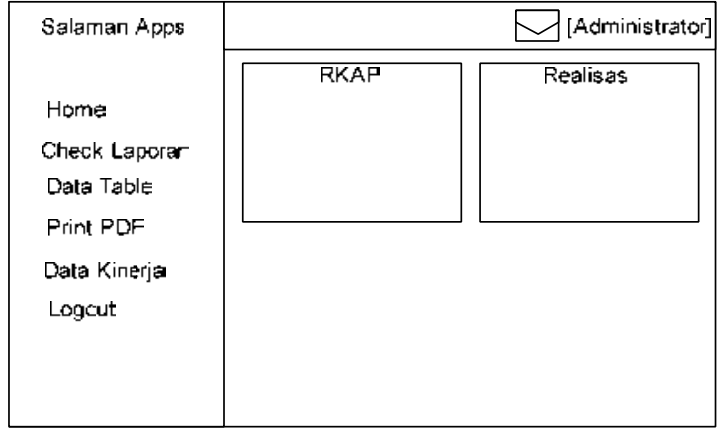

Gambar 19 Tampilan data table

\begin{tabular}{|c|c|c|}
\hline Salaman Apps I & & $D_{\text {[Nama afliasi }}$ \\
\hline Home & Perioce & \\
\hline Form Inpt & Perioce & \\
\hline Data Table & & \\
\hline & Subm I & \\
\hline Master Data & & \\
\hline Logitut & & \\
\hline
\end{tabular}

Gambar 20 Tampilan Cetak PDF

\begin{tabular}{|c|c|c|}
\hline \multirow[t]{2}{*}{ Salaman Apps' } & \multicolumn{2}{|r|}{ D[Nama Afiliz: } \\
\hline & Ko1t & peras Add Edit Dell \\
\hline Form Input & & Edit Dell \\
\hline Dala Tझाढ & $\mathrm{coz}$ & Edit Del \\
\hline Print PDF & & Edit Dell \\
\hline Logout & & \begin{tabular}{|l|l|} 
Edit Dol \\
\end{tabular} \\
\hline & & \\
\hline
\end{tabular}

Gambar 21 Tampilan Master Data

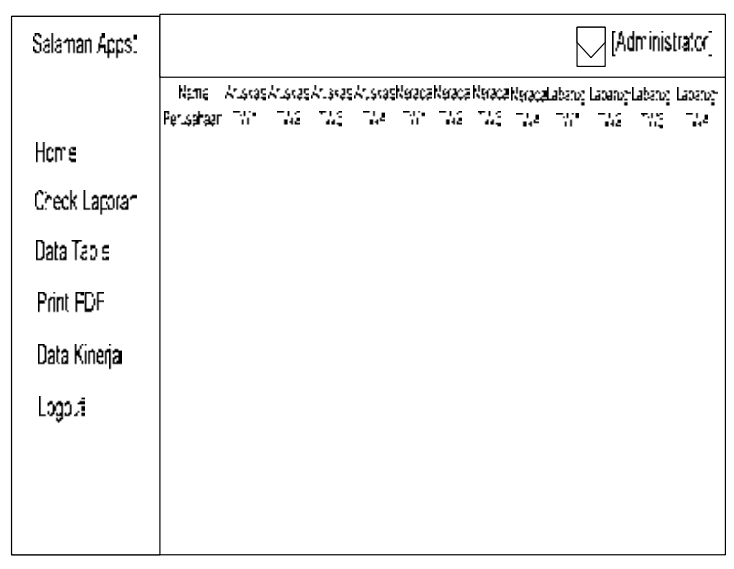

Gambar 22 Tampilan cek laporan 


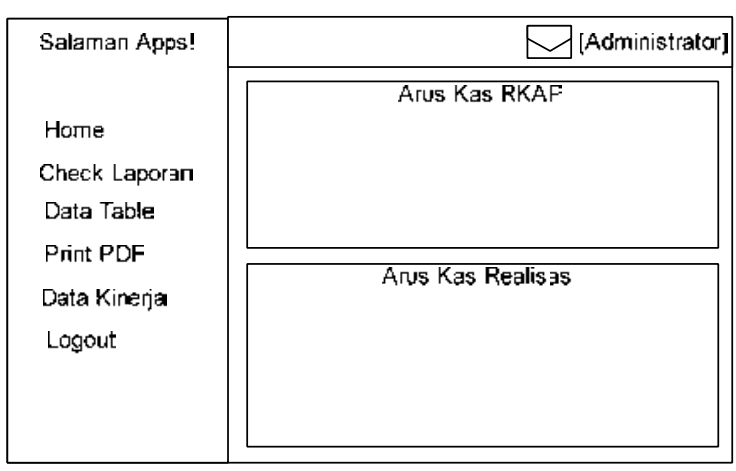

Gambar 23 Tampilan hasil data table

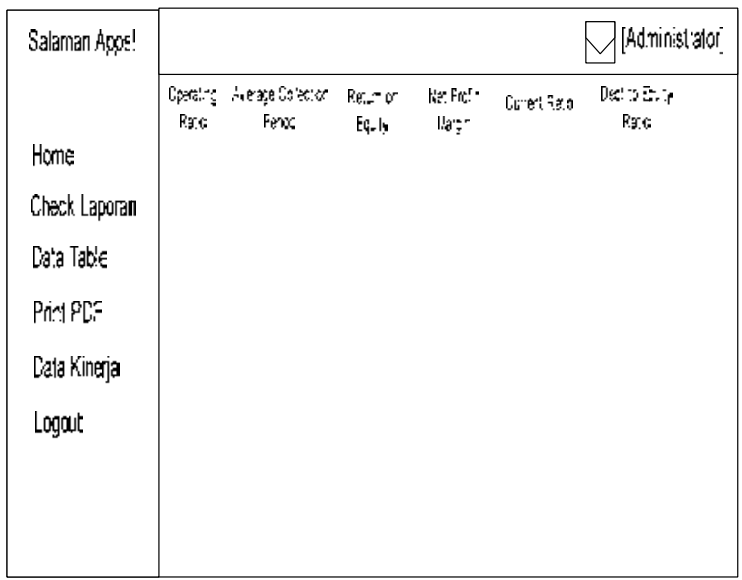

Gambar 24 Rancangan Tampilan Hasil Kinerja

\subsection{Hasil dan Pembahasan}

Dari paparan sebelum telah dijelaskan rancangan untuk membangun sistem penilaian hasil kinerja multi company dan cross business sector. Sistem yang dikembangkan tidak menutup kemungkinan menggunakan bahasa pemrograman berbasis web manapun.

Keberlanjutan dari sistem diatas yakni lanjutan dalam pengembangan sistem menggunakan rancangan UML 2,0. Rancangan terdiri dari behavioural model menggunakan use case diagram dan activity diagram serta structural model menggunakan class diagram.

Dalam mengembangkan antarmuka berbasis web diperlukan beberapa rancangan tampilan seperti yang telah digambarkan pada gambar16 gambar24. Antarmuka berbasis web disarankan menggunakan CSS3 dan bootstrap serta HTML.

Untuk rancangan database yang sesuai dengan sub judul 2.5 dapat diimplementasi kedalam database management system manapun. Berdasarkan sub judul 2.2 diperlukan DBMS MariaDB untuk membangun sistem ini.

\section{KESIMPULAN}

Rancangan sistem penilaian hasil kinerja multi company dan cross business sector dapat dirancngan menggunakan tools UML2.0 dengan menggunakan behavioural model menggunakan use case diagram dan activity diagram serta structural model menggunakan class diagram. Serta mengikuti kaidah dari waterfall SDLC dalam tahapan pengembangan perangkat lunaknya.

\section{DAFTAR PUSTAKA}

Alan Dennis, B. H. (2010). Systems Analysis and Design With UML version 2.0. Davers, USA: Wiley.

Asri, Y. (2012). Diktat Kuliah Sistem Informasi. Jakarta: Sekolah Tinggi Teknik - PLN.

Fitriana, V., Yohana Dewi Lulu W. S.Si., M., \& S.E.Ak, H. R. (2011). Sistem Informasi Akuntansi Keuangan Perusahaan Jasa Outsourcing .

Jogiyanto. (2005). Analisa dan Desain Sistem Informasi . Yogyakarta.

Putra, M. A. (2011). IMPLEMENTASI PROGRAM BANTUAN KEUANGAN PEUMAKMUE GAMPONG (BKPG) DI PROVINSI ACEH.

Sari, D. I. (2011). PEMBUATAN SISTEM INFORMASI KEUANGAN BERBASIS WEB PADA UD.SAPUTRA JAYA.

Septyawan, Y. (2014). SISTEM INFORMASI KEUANGAN KLINIK FIRDAUS.

Tenardi, W. (2013). Sistem Informasi Keuangan pada Sekolah ST.Agatha.

Tjokronolo, L. H. (2007). Peranan Sistem Informasi Keuangan terhadap kinerja perusahaan.

Trumper, L. V. (2008). Project Decisions, The Art and Science. Leesbugr Pike, Vienna: Management Concepts.

Wakang, H. M. (2012). Diktat Kuliah Rekayasa Perangkat Lunak. Jakarta: Sekolah Tinggi Teknik - PLN. 